\title{
Relevant radionuclides in Estonian drinking and ground waters - measurement techniques and activity concentrations
}

\author{
M. Kiisk, S. Suursoo, K. Isakar and R. Koch \\ Laboratory of Environmental Physics, Institute of Physics, University of Tartu, \\ Riia 142, 51014 Tartu, Estonia
}

\begin{abstract}
First comprehensive studies of the radionuclides' concentration and its composition in Estonian ground water began in 1990s. It was quickly realized that the activity concentration of ${ }^{226} \mathrm{Ra}$ and ${ }^{228} \mathrm{Ra}$ in Cambrian-Vendian $(\mathrm{Cm}-\mathrm{V})$ aquifer are the highest contributors to the total indicative dose (TID). About $22 \%$ of the population in Estonia uses $\mathrm{Cm}-\mathrm{V}$ ground water for drinking water supply. In recent study [1], it was concluded, that about $91 \%$ of $\mathrm{Cm}-\mathrm{V}$ aquifer consumers (20\% of the Estonian population) obtain higher TID doses (TID exceeding $0.1 \mathrm{mSv} / \mathrm{y}$ ) than set by European Commission and national regulations. Over the years, a good representation level by the number of measured samples for ${ }^{226} \mathrm{Ra}$ and ${ }^{228} \mathrm{Ra}$ from $\mathrm{Cm}-\mathrm{V}$ aquifer has been obtained. However, for other widely used aquifers - Ordovician-Cambrian, SilurianOrdovician and Devonian - only poor data is available. In several southern counties, only few percent of the water supplies have been surveyed. Data for other natural radionuclides $\left({ }^{234,238} \mathrm{U},{ }^{210} \mathrm{Po}\right.$ and $\left.{ }^{210} \mathrm{~Pb}\right)$ is also poor. Scarce data has been partly due to the lack of analysis techniques available in Estonian nuclear analysis laboratories. This has been the motivation in the development of gamma spectrometric and liquid scintillation (LSC) counting techniques for ground and drinking water applications.
\end{abstract}

\section{INTRODUCTION}

In Estonia, more intensively utilized aquifers are Quaternary (Q), Silurian (S), Ordovician (O), SilurianOrdovician (S-O), Ordovician-Cambrian (O-Cm) and Cambrian-Vendian (Cm-V) aquifer [2]. The Cambrian-Vendian aquifer system of the Baltic Basin is the major source of public water supply in North and North-East Estonia at the northernmost margin of the basin. Cambrian-Vendian groundwater covers about $75 \%$ in North and North-East and nearly 50\% in North-West Estonia of the total groundwater use in the area [3]. In the eastern part of the $\mathrm{Cm}-\mathrm{V}$ aquifer system, the Ediacaran clays of the Kotlin formation divide the system into two aquifers with different chemical and isotope compositions: Voronka (the upper) and Gdov (the lower) [4].

Majority of the knowledge on ground water radioactivity has been obtained during the last two decades. Main focus has been on $\mathrm{Cm}-\mathrm{V}$ aquifer system which is known to be rich in ${ }^{226} \mathrm{Ra}$ and ${ }^{226} \mathrm{Ra}$ concentrations. In 2005, a first summarizing investigation [5] concerning the radiological impact of ground water on the total dose estimate based on the existing data was made. It concluded that according to the existing data, approximately 230000 inhabitants consume water originating from $\mathrm{Cm}-\mathrm{V}$ aquifer. Approximately 184000 inhabitants (14\% of the Estonian population) within 41 municipalities and towns from the northern region of the country consume ground water with higher total indicative doses (TID) than set by national and European Commission regulation.

In 2009, another comprehensive study, Estonian-Italian Twinning project "Estimation of concentrations of radionuclides in Estonian ground waters and related health risks" [1] based on the existing data was carried out. According to the study, totally 225000 inhabitants (20\% of the total population) consume drinking water higher than recommended limit $0.1 \mathrm{mSv} / \mathrm{y}$, of which a vast majority of the population is $\mathrm{Cm}-\mathrm{V}$ aquifer consumers. The project also concluded that there is not enough data concerning the radioactivity available for the ground water other than $\mathrm{Cm}-\mathrm{V}$ aquifer system. 
As a consequence of the Twinning light project, in 2010, a new 2-years program was initiated by the national Health Board in order to extend the database and knowledge from the aquifers other than $\mathrm{Cm}-\mathrm{V}$. More than 200 samples will be collected and measured for ${ }^{226} \mathrm{Ra}$ and ${ }^{228} \mathrm{Ra}$ activity concentrations of Middle and south Estonia.

The scope of this paper is to provide concise overview on existing, publicly available radiological data concerning the ground waters and introduce the measurement techniques used or currently under development at the institute of Physics, University of Tartu.

\section{PRESENCE OF RADIONUCLIDES IN ESTONIAN GROUND WATERS}

An attempt to compile a database based on all publicly available measurements of radionuclides in Estonian ground water has been made. The accumulation of existing database dates back to 1961, but majority of the data originates from 1990-2010. The database has been compiled from data collected by government owned company Geological Survey of Estonia, Estonian Health Board and Institute of Physics, University of Tartu (limited with ${ }^{226} \mathrm{Ra}$ and ${ }^{228} \mathrm{Ra}$ results). Measurements have been performed by the radiation laboratory of Estonian Environmental Board, Finnish Nuclear Safety authority STUK and Institute of Physics, University of Tartu. Some measurements have been made in laboratories at St. Petersburg (Russion) and Riga (Latvia).

In Table 1, summary of the data collected over the years (1990-2010) is presented. During the period 1961-1990, 46 samples for ${ }^{226} \mathrm{Ra}$ measurements were made, unfortunately no information on the measurement techniques used is known. For the period 1990-2010, the analyzing laboratories are known, but cannot be associated currently to each individual measurement due to incomplete information in database.

The database contains information about 394 samples. Each sampling point is associated with a national registration number for a specific drilled well, date of sampling, type of aquifer and geographical coordinates. Due to multiple origin of the data, the quality of the data may vary and different sets of input contain different accompanying information: depth of the well is included for most of the sampling point. Uncertainty values do not exist for the periods 1.05.1961-1.01.2001 and 12.04.2005-4.03.2008. About 80 samples contain information on chemical parameters $-\mathrm{pH} ; \mathrm{K}, \mathrm{Ca}, \mathrm{Cl}$, $\mathrm{Mg}, \mathrm{HCO}_{3}, \mathrm{SO}_{4}, \mathrm{SiO}_{2}, \mathrm{Al}, \mathrm{F}, \mathrm{He}, \mathrm{Cd}, \mathrm{Mn}, \mathrm{Hg}$, Li concentrations. Less than 30 samples contain information on $\mathrm{Fe}, \mathrm{NH}_{4}, \mathrm{NO}_{3}, \mathrm{NO}_{2}, \mathrm{H}_{2} \mathrm{~S}, \mathrm{Ba}, \mathrm{Zn}, \mathrm{U}^{+}$.

Forty four additional samples have been measured by the Institute of Physics within 2009-2011, but are not included yet to the database due to incomplete information on location of the sampling point and type of aquifer information. However, these results have been used in applicability study [6] of gross $\alpha$ and $\beta$ activity measurements in case of high Ra activity concentrations in the background of ${ }^{40} \mathrm{~K}$.

As seen from Table 1, majority of measurements have been made for ${ }^{226} \mathrm{Ra}$ and ${ }^{228} \mathrm{Ra}$ from Cm$\mathrm{V}$ aquifer system and its two divided aquifers Gdov and Voronka from North-Eastern part of Estonia. There are some data on ${ }^{234} \mathrm{U},{ }^{238} \mathrm{U}$, but only few measurements on ${ }^{210} \mathrm{~Pb}$ and ${ }^{210} \mathrm{Po}$.

Table 2 presents average activity concentrations for ${ }^{226} \mathrm{Ra},{ }^{222} \mathrm{Rn}$ and ${ }^{228} \mathrm{Ra}$ with standard deviations and maximum obtained values from $\mathrm{Cm}-\mathrm{V}, \mathrm{V} 2 \mathrm{gd}, \mathrm{V} 2 \mathrm{vr}, \mathrm{O}-\mathrm{Cm} \mathrm{O}, \mathrm{S}$ and $\mathrm{D} 2$ aquifers. The highest average $\mathrm{Ra}$ values have been found within $\mathrm{Cm}-\mathrm{V}$ aquifer system. It can be noted that the standard deviations for Ra are relatively high.

There is much less data available for ${ }^{234} \mathrm{U}$ and ${ }^{238} \mathrm{U}$. In Table $3,{ }^{234} \mathrm{U}$ and ${ }^{238} \mathrm{U}$ results are presented. Clearly, ${ }^{234} \mathrm{U}$ activity concentrations are higher than ${ }^{238} \mathrm{U}$ in all the aquifers. This increased concentration has been explained by increased dissolution helped by the recoil process [7] of the parent nuclide ${ }^{238} \mathrm{U}$.

According to Ref. 8, $\mathrm{U}$ and $\mathrm{Ra}$ dissolution and precipitation occur at different geochemical conditions. Therefore, high $\mathrm{U}$ values may not be expected in $\mathrm{Cm}-\mathrm{V}, \mathrm{V} 2 \mathrm{gd}$, V2vr and O-Cm aquifers. Comparison of Tables 2 and 3 may have some indication to the negative correlation between Ra and $\mathrm{U}$. However, more data is needed to make any further conclusions. 
Table 1. Total number of publicly available radionuclide measurement results in different aquifer systems from the period 1990-2010. Sources of database: Geological Survey of Estonia, Estonian Health Board and Institute of Physics (only ${ }^{226} \mathrm{Ra}$ and ${ }^{228} \mathrm{Ra}$ ), Univ. of Tartu. ${ }^{40} \mathrm{~K}$ has been excluded from the table due to its irrelevance in TID calculations.

\begin{tabular}{|c|c|c|c|c|c|c|c|c|c|c|}
\hline Aquifer & $\begin{array}{c}\text { no. of } \\
\text { samples }\end{array}$ & ${ }^{226} \mathbf{R a}$ & ${ }^{228} \mathbf{R a}$ & ${ }^{222} \mathrm{Rn}$ & ${ }^{234} \mathbf{U}$ & ${ }^{238} \mathbf{U}$ & ${ }^{210} \mathrm{~Pb}$ & ${ }^{210} \mathrm{Po}$ & $\begin{array}{c}\text { gross } \\
\alpha\end{array}$ & $\begin{array}{c}\text { gross } \\
\beta\end{array}$ \\
\hline Cm-V & 104 & 101 & 78 & 20 & 22 & 22 & 10 & 10 & 21 & 21 \\
\hline V2gd & 87 & 84 & 55 & 22 & 13 & 13 & 7 & 7 & 24 & 24 \\
\hline V2vr & 75 & 72 & 57 & 11 & 6 & 6 & 3 & 3 & 13 & 13 \\
\hline O-Cm & 43 & 39 & 26 & 16 & 14 & 14 & & & 16 & 16 \\
\hline $\mathbf{O}$ & 29 & 24 & 8 & 19 & & & & & 16 & 16 \\
\hline $\mathbf{S}$ & 19 & 16 & 0 & 16 & & & & & 16 & 16 \\
\hline D2 & 24 & 22 & 3 & 20 & 1 & 1 & & & 19 & 19 \\
\hline $\mathbf{Q}$ & 5 & 2 & 2 & 1 & & & & & 0 & 0 \\
\hline D3 & 1 & 0 & 0 & 1 & & & & & 1 & 1 \\
\hline S-O & 3 & 3 & 2 & 1 & 1 & 1 & & & 1 & 1 \\
\hline $\mathrm{Cm}$ & 3 & 3 & 1 & 2 & & & & & 1 & 1 \\
\hline PR & 1 & 1 & 0 & 1 & & & & & 1 & 1 \\
\hline Total & 394 & 367 & 232 & 130 & 57 & 57 & 20 & 20 & 129 & 129 \\
\hline
\end{tabular}

Legend of the abbreviations: $\mathrm{Cm}-\mathrm{V}$ - Cambrian Vendian, V2gd - Gdov, V2vr - Voronka, O-Cm - OrdovicianCambrian, O - Ordovician, S -Silurian, D2 - Middle Devonian, Q - Quaternary, D3 - Upper Devonian, S-O Silurian-Ordovician, C1 - Lower Cambrian, PR - Crystalline Basement.

Table 2. Average activity concentrations $(\mathrm{Bq} / \mathrm{l})$ with standard deviations and maximum obtained values for ${ }^{226} \mathrm{Ra}$ and ${ }^{228} \mathrm{Ra}$ from $\mathrm{Cm}-\mathrm{V}$, Gdov, Voronka, $\mathrm{O}-\mathrm{Cm}$ and $\mathrm{O}$ aquifers.

\begin{tabular}{cccccccc}
\hline Aqifer & Cm-V & V2gd & V2vr & O-Cm & O & S & D2 \\
\hline no. of samples & 104 & 87 & 75 & 43 & 29 & 19 & 24 \\
Average ${ }^{\mathbf{2 2 6}} \mathbf{R a}$ & 0.34 & 0.46 & 0.34 & 0.16 & 0.07 & 0.05 & 0.03 \\
Average ${ }^{\mathbf{2 2 8}} \mathbf{R a}$ & 0.38 & 0.45 & 0.32 & 0.12 & 0.09 & - & - \\
Average ${ }^{\mathbf{2 2 2}} \mathbf{R n}$ & 14.5 & 16.8 & 9.2 & 19.4 & 12.1 & 9.0 & 14.3 \\
Max. ${ }^{\mathbf{2 2 2}} \mathbf{R a}$ & 0.80 & 3.63 & 2.73 & 0.56 & 0.23 & 0.13 & 0.04 \\
Max. ${ }^{\mathbf{2 2 8}} \mathbf{R a}$ & 0.92 & 1.01 & 1.48 & 0.25 & 0.10 & - & - \\
St.dev. ${ }^{\mathbf{2 2 6}} \mathbf{R a}$ & 0.17 & 0.44 & 0.39 & 0.14 & 0.06 & 0.03 & 0.01 \\
St.dev ${ }^{\mathbf{2 2 8}} \mathbf{R a}$ & 0.18 & 0,22 & 0.29 & 0.05 & 0.02 & - & -
\end{tabular}

The data concerning ${ }^{210} \mathrm{~Pb}$ and ${ }^{210} \mathrm{Po}$ is also limited, only $\mathrm{Cm}-\mathrm{V}$ aquifer system has been studied totally with 20 samples. In comparison to ${ }^{210} \mathrm{Po}$ values, ${ }^{210} \mathrm{~Pb}$ values indicate from these few results higher average and maximum values.

In Figure 1, a correlation between ${ }^{226} \mathrm{Ra}$ and ${ }^{228} \mathrm{Ra}$ from $\mathrm{Cm}-\mathrm{V}$ aquifer system is presented. According to the literature [9] the correlation cannot explicitly be assumed due to the origin from different natural families $\left({ }^{238} \mathrm{U}\right.$ and $\left.{ }^{232} \mathrm{Th}\right)$. However, weak, but statistically significant correlation $\left(\mathrm{R}^{2}=0.4206\right.$, Slope $=0.7149$, intercept $\left.=0.1485\right)$ has been found. This is somewhat lower than found in the final report of the Twinning project $\left(\mathrm{R}^{2}=0.536\right)$ [1]. Since the report does not describe explicitly the database used, the reasons for the discrepancy cannot be studied. In order to understand the difference, both databases should be compared. In addition to the correlation between Ra isotopes, the Twinning project made correlation studies between Ra and chemical parameters. For example, linear regression analysis indicated strong correlation $\left(\mathrm{R}^{2}=0.802\right)$ between ${ }^{228} \mathrm{Ra}$ activity concentrations and water mineralization. A weaker relation $\left(\mathrm{R}^{2}=0.590\right)$ was found between mineralization and ${ }^{226} \mathrm{Ra}$. 
Table 3. Average activity concentrations $(\mathrm{Bq} / \mathrm{l})$ with standard deviations and maximum obtained values for ${ }^{234} \mathrm{U}$ and ${ }^{238} \mathrm{U}$ from $\mathrm{Cm}-\mathrm{V}$, Gdov, Voronka, O-Cm, D2 and S-O aquifers and average activity concentrations $(\mathrm{Bq} / \mathrm{l})$ with standard deviations and maximum obtained values for ${ }^{210} \mathrm{~Pb}$ and ${ }^{210} \mathrm{Po}$ from $\mathrm{Cm}-\mathrm{V}$, Gdov and Voronka aquifers.

\begin{tabular}{ccccccccccc}
\hline Aquifer & $\mathrm{Cm}-\mathrm{V}$ & $\mathrm{V} 2 \mathrm{gd}$ & $\mathrm{V} 2 \mathrm{vr}$ & $\mathrm{O}-\mathrm{Cm}$ & $\mathrm{D} 2$ & $\mathrm{~S}-\mathrm{O}$ & Aqifer & $\mathrm{Cm}-\mathrm{V}$ & $\mathrm{V} 2 \mathrm{gd}$ & $\mathrm{V} 2 \mathrm{vr}$ \\
\hline Samples no. & 22 & 13 & 6 & 14 & 1 & 1 & Samples no. & 10 & 7 & 3 \\
Aver. ${ }^{234} \mathrm{U}$ & 0.005 & 0.009 & 0.003 & 0.003 & 0.007 & 0.016 & Aver. ${ }^{210} \mathrm{~Pb}$ & 0.057 & 0.049 & 0.023 \\
Aver. ${ }^{238} \mathrm{U}$ & 0.001 & 0.001 & - & 0.001 & 0.004 & 0.005 & Aver. ${ }^{210} \mathrm{Po}$ & 0.014 & 0.008 & 0.004 \\
St.dev. ${ }^{234} \mathrm{U}$ & 0.003 & 0.011 & 0.004 & 0.002 & - & - & St.dev. ${ }^{210} \mathrm{~Pb}$ & 0.027 & 0.034 & 0.023 \\
St.dev. ${ }^{238} \mathrm{U}$ & 0.001 & 0.001 & - & 0.001 & - & - & St.dev. ${ }^{210} \mathrm{Po}$ & 0.039 & 0.005 & 0.003 \\
Max. ${ }^{234} \mathrm{U}$ & 0.007 & 0.039 & 0.010 & 0.006 & 0.007 & 0.016 & Max. ${ }^{210} \mathrm{~Pb}$ & 0.100 & 0.090 & 0.050 \\
Max. ${ }^{238} \mathrm{U}$ & 0.002 & 0.002 & - & 0.002 & 0.004 & 0.005 & Max. ${ }^{210} \mathrm{Po}$ & 0.130 & 0.016 & 0.007 \\
\hline
\end{tabular}

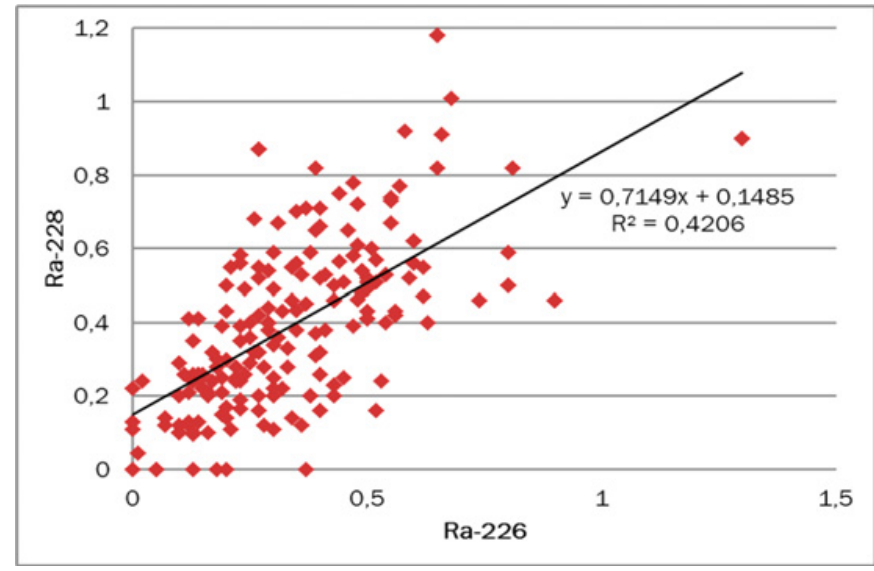

Figure 1. Correlation between ${ }^{226} \mathrm{Ra}$ and ${ }^{228} \mathrm{Ra}$ in Cambrian-Vendian, Gdov and Voronka aquifer.

\section{MEASUREMENT TECHNIQUES AND PROCEDURES}

\subsection{Gamma-ray spectrometry}

A gammaspectometrical nuclide specific procedure was used to obtain ${ }^{226} \mathrm{Ra},{ }^{228} \mathrm{Ra}$ and ${ }^{40} \mathrm{~K}$ activity concentrations. About 3 liters of water was used for the sample preparation. The water samples were first acidified with concentrated nitric acid to $\mathrm{pH} 1 \ldots 2$. Then the water was evaporated to dryness, and residue was put into an aluminum can. To obtain the same geometry for all the samples the residue was mixed with $5 \mathrm{~g}$ of Epoxy resin into a homogeneous mass. After about 2 hours of drying the can was hermetically sealed. Measurements were made with a coaxial HPGe gamma-ray spectrometer GEM35200 (manufacturer EG\&G ORTEC; relative efficiency 42\%; resolution $1.75 \mathrm{keV}$ at $1.3 \mathrm{MeV}$ ). To achieve better statistics the duration of each measurement was about 24 hours. Typically, one sample was measured three times. The last measurement was done about 3 weeks after the sealing of the sample to allow the ingrowth of ${ }^{222} \mathrm{Rn}$ and its short lived progeny.

The spectra were analyzed with a GammaVision software (manufacturer EG\&G ORTEC; version 6.07). The activity of ${ }^{228} \mathrm{Ra}$ was calculated according to the full energy peaks of its daughter nuclide ${ }^{228}$ Ac. The peaks of $911.20 \mathrm{keV}, 964.76 \mathrm{keV}$ and $968.97 \mathrm{keV}$ were used. The activity of ${ }^{226} \mathrm{Ra}$ was calculated from its daughter nuclides ${ }^{214} \mathrm{~Pb}(242.00 \mathrm{keV}, 295.22 \mathrm{keV}, 351.93 \mathrm{keV})$ and ${ }^{214} \mathrm{Bi}(609.32 \mathrm{keV}$, $1120.29 \mathrm{keV}, 1764.49 \mathrm{keV}) .{ }^{40} \mathrm{~K}$ activity was obtained from its $1460.60 \mathrm{keV}$ full energy peak. Minimum detectable activity with given conditions are in the range of $15 \mathrm{mBq} / 1\left({ }^{228} \mathrm{Ra}\right)$ and $20 \mathrm{mBq} / \mathrm{l}\left({ }^{228} \mathrm{Ra}\right)$. 
The efficiency and energy calibrations of the gammaspectrometer were done using a standard calibration sample of $3 \mathrm{~g}$ IAEA RGU1 sand (for ${ }^{226} \mathrm{Ra}$ calibration), IAEA RGTh-1 sand (for ${ }^{228} \mathrm{Ra}$ ) and IAEA RGK-1 sand mixed with $5 \mathrm{~g}$ of Epoxy resin. The background sample was made of $5 \mathrm{~g}$ Epoxy resin.

\section{$3.2{ }^{226} \mathrm{Ra},{ }^{222} \mathrm{Rn}$ procedures with $\mathrm{LSC}$}

Liquid scintillation $\mathrm{n}$ counting (LSC) with alpha/beta separation technique (portable Hidex Triathler counter) has been applied for ${ }^{226} \mathrm{Ra}$ measurements. Two-phase cocktails Maxilight (by Hidex) for ${ }^{222} \mathrm{Rn}$ extraction have been used. Samples acidified with nitric acid to $\mathrm{pH} 1 . .2$ are preconcentrated 2-4 fold prior measurement procedure. Detection efficiency $260 \pm 19 \%$ for ${ }^{226} \mathrm{Ra}$ has been determined by the ${ }^{226} \mathrm{Ra}$ standard source EB 95 (aqueous solution, $1 \mathrm{~g} \mathrm{BaCl}_{2} / 1$ and $10 \mathrm{~g} \mathrm{HCl} / 1$, Eurostandard $\mathrm{CZ}$ ltd. s.r.o.).

\section{3 ${ }^{210}$ Po procedure with LSC}

Water samples were acidified with concentrated nitric acid to $\mathrm{pH} 1 \ldots 2$. Then, a procedure recommended by ETRAC Laboratories Inc. [10] was applied. It is based on extracting polonium from water into the scintillation cocktail Polex. The procedure has two steps: extraction of Po and U from aqueous phase and separation of $\mathrm{U}$ from cocktail phase by using $\mathrm{H}_{3} \mathrm{PO}_{4}$ and $0.001 \mathrm{M} \mathrm{HCl}$ in different steps of the procedure.

Procedures yield is determined with a ${ }^{209} \mathrm{Po}$ standard source $\left(1 \mathrm{M} \mathrm{HNO}_{3}\right.$ water solution, Oak Ridge National Laboratory).

The sample was measured on a portable LSC-counter Hidex Triathler. Measurement time ranged from 10 to 24 hours depending on the activity of the sample. Blank sample has been prepared using distilled water in described procedure.

\subsection{Uranium procedure}

Water samples were acidified with concentrated nitric acid to $\mathrm{pH} 1 \ldots 2$. The procedure is based on extracting uranium from water into the scintillation cocktail phase with adding a complexing agent bis(2-ethylhexyl)phosphoric acid (HDEHP) to it [11]. $300 \mu \mathrm{l}$ of HDEHP was used per $5 \mathrm{ml}$ of Betaplate Scint cocktail. The amount of water used ranged from $25 \mathrm{ml}$ to $100 \mathrm{ml}$. Betaplate Scint, HDEHP and the water was mixed in a separation funnel. The system was shaken vigorously for about one minute. Then the phases were let to separate for about one hour. After that the water phase was removed and about $3 \mathrm{ml}$ of the cocktail phase was pipetted into a LSC-vial. Before sealing the sample, argon was bubbled through the cocktail phase for two minutes to remove radon.

The sample was measured on a portable LSC-counter Triathler. Measurement time ranged from 10 to 24 hours depending on the activity of the sample. The yield determination for the procedure has not yet in place.

\subsection{Gross alpha/beta procedure}

Water samples were acidified with concentrated nitric acid to $\mathrm{pH} 1 \ldots 2.20 \mathrm{ml}$ of the sample was pipetted into a LSC-vial and evaporated under an infrared lamp to $8 \mathrm{ml} .12 \mathrm{ml}$ of AquaLight cocktail was added. Residual radon was removed. $20 \mathrm{ml}$ glass vials with teflon coated caps were used.

The sample was measured on a portable LSC-counter Triathler after keeping the vial in darkness for 1 hour. Extra shielding was used to minimize the background noise - lead bricks of $10 \mathrm{~cm}$ from bottom, $8 \mathrm{~cm}$ from the sides and $4 \mathrm{~cm}$ from top. Measurement time ranged from 10 to 24 hours depending on the activity of the sample. 


\section{CONCLUSIONS}

Database on radionuclides concentration in ground water based on the measurement results from 19902010 has been collected. Majority of the data are activity concentrations of ${ }^{226} \mathrm{Ra}$ and ${ }^{228} \mathrm{Ra}$ in $\mathrm{Cm}-\mathrm{V}$, Gdov and Voronka aquifers. Some data exist for O-Cm, O, S and D2 aquifers. Existing data on U, ${ }^{210} \mathrm{~Pb}$ and ${ }^{210} \mathrm{Po}$ suggest, that they are not major contributors to TID in drinking water originating from $\mathrm{Cm}$ $\mathrm{V}$ aquifer, but should not be discarded before the database has been further extended. The quality of the data should be improved as much as possible by associating specific measurements with specific analysing laboratories and the analysing techniques used.

Gammaspectrometry has been applied on water samples for ${ }^{226} \mathrm{Ra}$ and ${ }^{228} \mathrm{Ra}$ measurements. The main advantage of the procedure is its robustness. It is not sensitive to the $\mathrm{pH}$ of the water sample. Because no chemical separation is made, all gamma emitting isotopes can be detected. However, the main drawback of the procedure is high time consumption. The technique is currently under preparation for accreditation by the end of 2011.

LSC-techniques for ${ }^{226} \mathrm{Ra},{ }^{210} \mathrm{Po}$ and $\mathrm{U}$ are currently in different phases under development.

\section{References}

[1] Forte M., Rusconi R., Trotti F., Caldognetto, E., Airoldi R., Realini F., Risica S., Bagnato L.,. "Estimation of concentrations of radionuclides in Estonian ground waters and related health risks", Final Report. Milano: Agenzia Regionale per la Protezione dell' Ambiente della Lombardia (Twinning Light Contract EE06-IB-TWP-ESC-03, 2010).

[2] Perens R. and Vallner L., "Water bearing formation" in Geology and Mineral Resources of Estonia (Estonian Academy Publishers, Tallinn, 1997) pp. 137-145.

[3] Karise, V., Composition and properties of groundwater under natural conditions. In: Raukas, A., Teedumäe, A. (Eds.), Geology and Mineral Resources of Estonia 1997. Estonian Academy Publishers, Tallinn, pp. 152-156.

[4] Raidla V., Kirsimäe K., Vaikmäe R., Jõeleht A., Karro E., Marandi A., Savitskaja L., Chemical Geology 258 (2009) 219-231.

[5] Centre of Radioprotection "Joogivee radioaktiivsusest põhjustatud terviseriski hinnang", 2005.

[6] Suursoo S., Kiisk M., Jantsikene A., Isakar K., Koch R., "Applying gross alpha and beta measurements as an estimate to the total indicative dose of Cambrian-Vendian groundwater in Estonia”, presented at Int. conf. on Radioecology and Environmental Radioactivity, June 19-24 2011, Hamilton, Canada

[7] Chalupnik S. (2008): "Radium transfer from solid to liquid phase - a theoretical approach to its behaviour in aquifers" in "Uranium, mining and hydrogeology" Merkel B.J., Hasche-Berger A., Springer.

[8] Clark I., Fritz P., in Environmental Isotopes in Hydrogeology (CRC press//Lewis Publishers 1997) p. 238-241

[9] IAEA "The environmental behaviour of radium", Technical Report (STI/DOC/10/310, Vienna 1990).

[10] McDowell W.J., McDowell B.L., "Liquid Scintillation Alpha Spectrometry" (CRC press, Maryland, US, 1994).

[11] Venso E.A., Prichard H.M and Dodson C.L., Radiocarbon (1993) 425-430. 